\title{
Relation between Compressive Strength of Baked Clay Cubes and Cylinders
}

\author{
Nawab Ali Lakho, Muhammad Auchar Zardari* \\ Department of Civil Engineering, Quaid-e-Awam University of Engineering, Science and Technology, \\ Nawabshah, Pakistan \\ Email: "muhammad.auchar@quest.edu.pk
}

Received 2 August 2016; accepted 22 August 2016; published 25 August 2016

Copyright (C) 2016 by authors and Scientific Research Publishing Inc.

This work is licensed under the Creative Commons Attribution International License (CC BY). http://creativecommons.org/licenses/by/4.0/

c) (5) Open Access

\begin{abstract}
Reinforced Baked Clay (RBC) seems to be potential alternative of Reinforced Cement Concrete (RCC) for construction of low cost houses. In order to utilize RBC as a construction material for buildings, it is necessary to understand compression behaviour of baked clay. In this paper, relation between cube crushing strength and cylinder strength of baked clay is presented. For this purpose, clay beams were cast in a mould and compacted at a pressure of $6 \mathrm{MPa}$. The clay beams were dried and fired in a kiln at a temperature of $900^{\circ} \mathrm{C}$. Cubes of $150 \mathrm{~mm}$ size were sawed from a baked clay beam. Cylinders of $150 \mathrm{~mm}$ diameter and $300 \mathrm{~mm}$ height were cut, from another baked clay beam, using core cutter machine. Both the cubes and cylinders were tested for compressive strength in Universal Testing Machine. The results showed that the cube crushing strength of baked clay was $25 \mathrm{MPa}$ and the ratio of the compressive strength of the cylinders and the cubes was found to be 0.6 . Suggestions for improvement of compressive strength of baked clay cylinders are also discussed.
\end{abstract}

\section{Keywords}

Baked Clay, Compressive Strength, Cubes, Cylinders, Low Cost Houses

\section{Introduction}

Uncontrolled population growth in Pakistan has resulted in tremendous shortfall in housing units [1]. This problem is aggravated due to increase in cost of traditional materials of building construction, i.e., aggregates, cement and steel. This problem of shortage of houses could possibly be resolved by using local materials of building construction. Clay is one of the potential materials of building construction in plains of Pakistan. Clay is

\footnotetext{
*Corresponding author.
} 
available in enormous volume in plain regions. Clay can be quarried economically at a shallow depth without need of much specialized machinery and manpower. The proposed idea is to utilize Reinforced Baked Clay (RBC) as a substitute of Reinforced Cement Concrete (RCC) for construction of low cost houses. At this stage, precast panels of clay beams could be cast, fired and post reinforced and could be utilized for construction of low cost houses [2]-[7]. In order to further enhance the use of RBC as a low cost material of building construction, more detailed research is required to be conducted to understand its behaviour.

Since compressive strength of concrete is considered to be an important property because of load carrying capacity, elastic modulus and tensile strength are dependent on it. Generally compressive strength of concrete is determined by testing standard size cubes or cylinders. Up to this stage, the compressive strength of cubes cut from baked clay beams compacted at various intensities of compaction is investigated only [2]-[7]. Previous studies report that the compressive strength of baked clay cubes is comparable to that of normal concrete [2]-[7]. The compressive strength of baked clay cubes depends on compaction at the time of casting [8] and firing temperature [9]-[11].

Up to yet, no work is reported in the literature regarding compressive strength of baked clay cylinders. In codes of practice, generally, compressive strength of cylinders is used for design of various structural members of a building. In order to formulate the codes for use of RBC as a construction material in buildings, it is necessary to investigate the compressive strength of baked clay cylinders and find its relation with corresponding compressive strength of baked clay cubes. Therefore, this study was conducted to determine the relation between cube crushing strength and compressive strength of baked clay cylinders.

\section{Materials and Methods}

\subsection{Preparation of Clay and Pit Sand Mixture}

Clay was obtained locally at a depth of $1200 \mathrm{~mm}$. Clay was ground in a Pulverizer after drying. Forty-two percentage of clay was replaced with pit sand in order to reduce shrinkage. Quantity of water added was $22 \%$ of the mixture of clay and pit sand by weight. Mixing of the whole mixture was carried out in a pan mixture for fifteen minutes.

\subsection{Casting of Baked Clay Beams}

Clay beams of dimensions $150 \mathrm{~mm} \times 300 \mathrm{~mm} \times 1980 \mathrm{~mm}$ were cast in a steel mould by putting moist mixture of clay and pit sand in five layers. The beams were mechanically pressed at a pressure of $6 \mathrm{MPa}$ using a Mechanized System [12] as shown in Figure 1. The beams were then dried and baked in a kiln at a temperature of

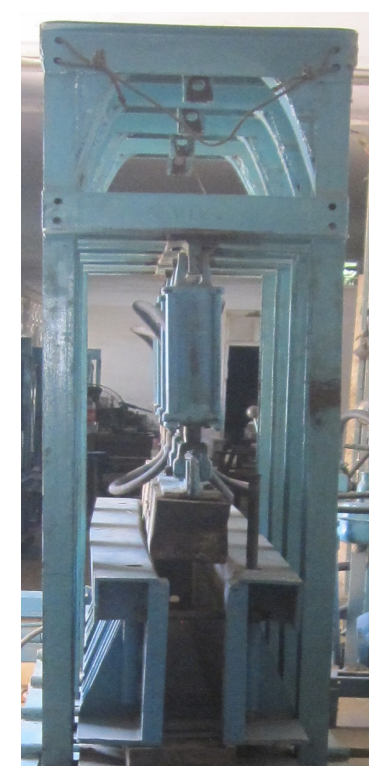

Figure 1. A clay beam is being cast and compacted in a Mechanized System. 
$900^{\circ} \mathrm{C}$. Cubes of $150 \mathrm{~mm}$ size were sawed from a baked clay beam. Cylinders of $150 \mathrm{~mm}$ and $300 \mathrm{~mm}$ height were cut from another baked clay beam using core cutter machine (Figure 2). A view of a baked clay cylinder core is shown in Figure 3.

\subsection{Testing Programme}

Both the baked clay cylinders and cubes were tested in Universal Testing Machine (Figure 4). The cubes were tested using British Standard BS EN 12390-3 [13] and the cylinders were tested in accordance with ASTM C873 [14] and ASTM C39 [15]. For testing of the cubes and cylinders, the load was applied in a direction perpendicular to the casting layers.

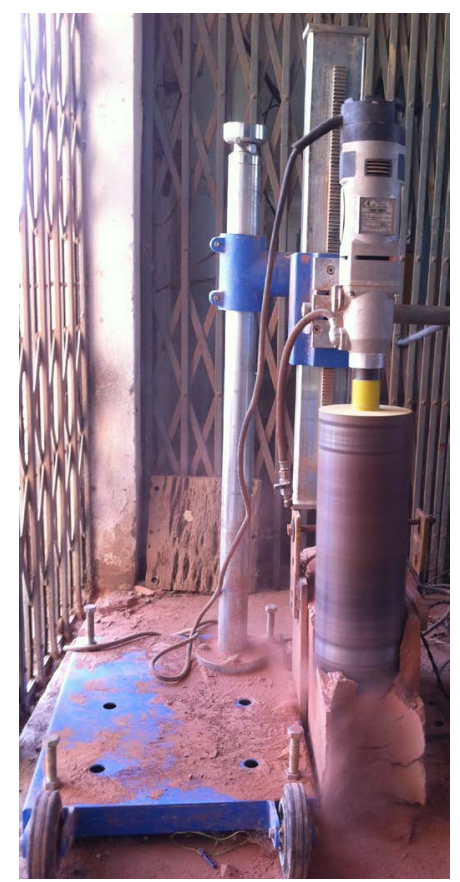

Figure 2. A baked clay cylinder is being cut with core cutter machine.

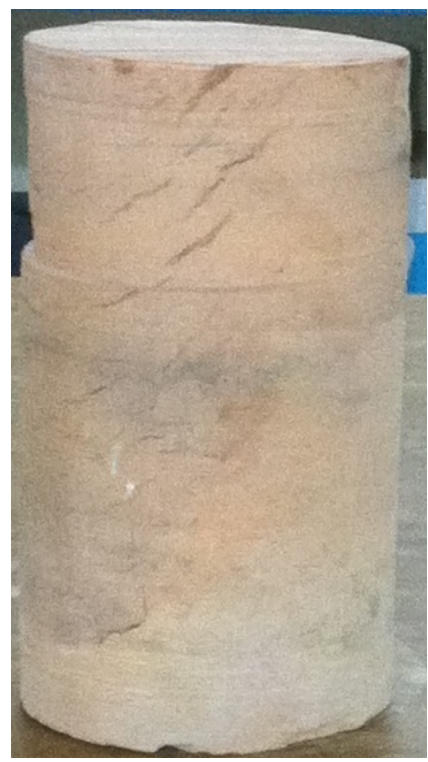

Figure 3. A baked clay cylinder core of $150 \mathrm{~mm}$ diameter and $300 \mathrm{~mm}$ height. 


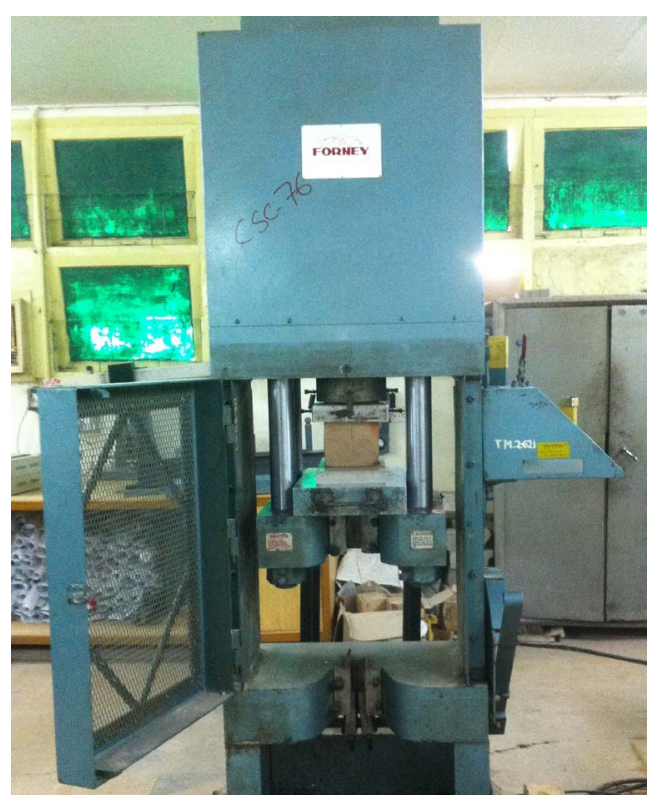

Figure 4. Baked clay cubes of $150 \mathrm{~mm}$ size are being tested in Universal Testing Machine.

Table 1. Compressive strength of baked clay cubes of $150 \mathrm{~mm}$ size.

\begin{tabular}{ccc}
\hline S. No. & Sample ID & Compressive strength (Mpa) \\
\hline 1 & C1 & 25.6 \\
2 & C2 & 26.3 \\
3 & C3 & 25.1 \\
4 & C4 & 26 \\
5 & C5 & 24.5 \\
6 & C6 & 26.9 \\
7 & C7 & 24.7 \\
8 & C8 & 25.3 \\
9 & C9 & 25 \\
10 & C10 & 25.2 \\
\hline
\end{tabular}

\section{Results and Discussions}

\subsection{Compressive Strength of Baked Clay Cubes}

Ten baked clay cubes were tested in compression. Compressive strength of the cubes is presented in Table 1 . Average cube crushing strength was found to be $25 \mathrm{MPa}$. It is to be noted that cube crushing strength of normal concrete is $20 \mathrm{MPa}$ [13]. This implies that compression behaviour of baked clay cubes is as good as normal concrete.

\subsection{Compressive Strength of Baked Clay Cylinders}

Ten samples of baked clay cylinders were tested in compression in Universal Testing Machine. The compressive strength of the cylinders is presented in Table 2. Average compressive strength of the cylinders was found to be $15 \mathrm{MPa}$. This implies that the compressive strength of baked clay cylinders was found to be 0.6 times the cube crushing strength. This ratio of cylinder strength to cube strength of baked clay seems to be less than that of concrete, which is 0.8 [16]. This may be due to presence of voids and drying cracks in relatively more volume of a cylinder as compared to a baked clay cube. It is to be noted that both the cylinders and cubes were cut from baked clay beams. The beams were cast in five equal layers, each of thickness $60 \mathrm{~mm}$. The cubes contained 
Table 2. Compressive strength of baked clay cylinders of diameter $150 \mathrm{~mm}$ and height $300 \mathrm{~mm}$.

\begin{tabular}{ccc}
\hline S. No. & Sample ID & Compressive strength (Mpa) \\
\hline 1 & S1 & 15.2 \\
2 & S2 & 14.7 \\
3 & S3 & 15.4 \\
4 & S4 & 15.3 \\
5 & S5 & 14.8 \\
6 & S6 & 14.5 \\
7 & S7 & 14.9 \\
8 & S8 & 15 \\
9 & S9 & 15.6 \\
10 & S10 & 15 \\
\hline
\end{tabular}

maximum of three layers and the cylinders involved all the five layers.

Since the compressive strength of a cylinder is considered to be more realistic for design of structural compression members, it is suggested to conduct further studies to minimize the voids and drying cracks in clay beams in order to achieve compressive strength of baked clay cylinders as high as exhibited by normal concrete.

\section{Conclusions}

The compressive strength of cubes and cylinders that were obtained from baked clay beams fired at $900^{\circ} \mathrm{C}$ is described in this paper. Following conclusions can be drawn:

1) Average Compressive strength of the cubes was found to be $25 \mathrm{MPa}$ which is $25 \%$ more than cube crushing strength of normal concrete.

2) Average compressive strength of baked clay cylinders was $15 \mathrm{MPa}$. This implies that compressive strength of baked clay cylinders is about 0.6 times the cube crushing strength. The ratio of cylinder to cube crushing strength of baked clay is less than that of normal concrete, which is 0.8 .

3) Future studies are suggested to be carried out to reduce voids and drying cracks in baked clay beams in order to enhance compressive strength of cylinders.

\section{Acknowledgements}

The authors would like to thank Quaid-e-Awam University of Engineering, Science and Technology Nawabshah, for providing access to the Structural Engineering Laboratory to conduct the tests mentioned in this study.

\section{References}

[1] Malik, S. and Julaihi, W. (2010) Rapid Urbanization: Problems and Challenges for Adequate Housing in Pakistan. Journal of Sociology and Social Work, 2, 87-110.

[2] Ansari, A.A., Bhatti, N.K. and Bhutto, A. (2013) Suitability of Pre-Perforated Post-Reinforced Baked Clay Beam Panels for Low Cost Housing. American Journal of Civil Engineering, 1, 6-15. http://dx.doi.org/10.11648/j.ajce.20130101.12

[3] Ansari, A.A. and Lakho, N.A. (2013) Determination of Structural Properties of Baked Clay as Replacement of RCC. International Journal of Emerging Technology and Advanced Engineering, 3, 17-25.

[4] Ansari, A.A. (2008) Experimental Study of the Behaviour of Pre-Perforated Post-Reinforced Baked Clay Panels of Beams. PhD Thesis, Quaid-e-Awam University of Engineering Science and Technology, Nawabshah.

[5] Lakho, N.A. and Zardari, M.A. (2016) Comparison of Compressive and Tensile Strength of Baked Clay with Those of Normal Concrete. Engineering, 8, 301-307. http://dx.doi.org/10.4236/eng.2016.86027

[6] Lakho, N. and Zardari, M.A. (2016) Experimental Study of Flexural Behaviour of Reinforced Baked Clay Beams under Impact Loading. Engineering, 8, 347-352. http://dx.doi.org/10.4236/eng.2016.86032

[7] Lakho, N.A. and Zardari, M.A. (2016) Flexural Behaviour of Reinforced Baked Clay Beams. Engineering, 8, $403-409$. http://dx.doi.org/10.4236/eng.2016.87037 
[8] Lakho, N.A., Zardari, M.A. and Memon, F.A. (2016) Effect of Intensity of Compaction on Crushing Strength of Indigenous Baked Clay. Journal of Engineering Research, 2, 18-28.

[9] Karaman, S., Ersahin, S. and Gunal, H. (2006) Firing Temperature and Firing Time Influence on Mechanical and Physical Properties of Clay Bricks. Journal of Scientific and Industrial Research, 65, 153-159.

[10] Karaman, S., Gunal, H. and Ersahin, S. (2006) Assessment of Clay Bricks Compressive Strength Using Quantitative Values of Colour Components. Construction and Building Materials, 20, 348-354. http://dx.doi.org/10.1016/j.conbuildmat.2004.11.003

[11] Johari, I., Said, S., Hisham, B., Bakar, A. and Ahmad, Z.A. (2010) Effect of the Change of Firing Temperature on Microstructure and Physical Properties of Clay Bricks from Beruas (Malaysia). Science of Sintering, 42, 245-254. http://dx.doi.org/10.2298/SOS1002245J

[12] Lakho, N.A., Zardari, M.A., Memon, M. and Saand, A. (2015) Design and Fabrication of Mechanized System for Casting and Compacting Laboratory Size Clay Beams. Scientia Iranica, 22, 2046-2051.

[13] BS EN 12390-3 (2009) Testing Hardened Concrete-Part 3: Compressive Strength of Test Specimens. Management Centre: Avenue Marnix 17, Brussels.

[14] ASTM C873/C873M (2015) Standard Test Method for Compressive Strength of Concrete Cylinders Cast in Place in Cylindrical Molds. ASTM International, West Conshohocken.

[15] ASTM C39/C39M (2016) Standard Test Method for Compressive Strength of Cylindrical Concrete Specimens. ASTM International, West Conshohocken.

[16] Neville, A.M. (2011) Properties of Concrete. Pearson Education Limited, Essex.

\section{Submit or recommend next manuscript to SCIRP and we will provide best service for you:}

Accepting pre-submission inquiries through Email, Facebook, LinkedIn, Twitter, etc.

A wide selection of journals (inclusive of 9 subjects, more than 200 journals)

Providing 24-hour high-quality service

User-friendly online submission system

Fair and swift peer-review system

Efficient typesetting and proofreading procedure

Display of the result of downloads and visits, as well as the number of cited articles

Maximum dissemination of your research work

Submit your manuscript at: http://papersubmission.scirp.org/ 